\title{
Evoking premiumness: How color-product congruency influences premium evaluations
}

\author{
Sarah Joy Lyons ${ }^{\mathrm{a}, *}$, Anders Hauge Wien ${ }^{\mathrm{b}}$ \\ a Department of Consumer Marketing, Muninbakken 9-13, 9291 Tromsø, Norway \\ b The Arctic University of Norway, the School of Business and Economics, Department of Marketing, Norway
}

\section{A R T I C L E I N F O}

\section{Keywords:}

Framing effects

Hedonic-utilitarian

High quality

Functional positioning

Experiential benefits

Congruency

\begin{abstract}
A B S T R A C T
Green is commonly used in marketing to evoke utilitarian and environmental cues, whereas red is regularly found on food logos to induce arousal and excitement. This paper investigates how these colors may contribute to consumer evaluations of premiumness through congruence and incongruence between the marketing message and color on product packages. The literature suggests that, although congruence between product elements and the marketing message often is evaluated as more appropriate, a "moderate incongruence effect" may result in consumer preferences for a moderate incongruence between design elements. Two between-subject experiments suggest that the premise of congruity or incongruity applies to explaining how colors may evoke higher premium evaluations. Study 1 demonstrates that for a product of hedonic nature, consumers will evaluate the product as more premium when the color and product framing are congruent (e.g., red on a package framed as "tasting delicious" or green on a package sold as "healthy"). Study 2 demonstrates the opposite effect by suggesting that when a product is primarily utilitarian, it will be perceived as more premium when the framing of the product and the color are incongruent (e.g., green on the package marketed for its "delicious taste" or red on the package sold as "healthy"). The study adds a novel understanding of how the mechanism of congruence and incongruence between color and a hedonic versus utilitarian marketing message can lead to premium associations. It also has practical implications for marketing managers as to how one can enhance the premium evaluations through color and marketing message.
\end{abstract}

\section{Introduction}

With the food marketers increasingly aiming at product differentiation based on premiumness (The Nielsen Company, 2015), it is critical to understand how colors add to consumer perceptions of premium value. Color choice is an important part of the visual equity of a product, which is the value derived from the visual form of the product (Bottomley \& Doyle, 2006). Although a few studies indicate that darker colors will lead to higher price and quality perceptions (Ampuero \& Vila, 2006; Ares \& Deliza, 2010; Labrecque \& Milne, 2013; Loose \& Szolnoki, 2012), there remains a gap in the literature as to how color can influence consumer perceptions of premiumness.

We define premium products as those products that intend to generate overall higher quality and price perceptions through additional attributes and selective distribution (Quelch, 1987; Vigneron \& Johnson, 2004), yet also are associated with extrinsic aspects such as the product's uniqueness or social image (Anselmsson, Vestman Bondesson, \& Johansson, 2014). Based on the notion that packaging serves as an extrinsic cue for product quality, signaling to the consumer if it is justifiable to pay a premium price (Bredahl, 2004), we investigated specifically how the color of the product can lead to perceived premiumness by consumers.

Color research on food packaging in a retail environment first and foremost has focused on identification of flavor and the color of the food itself, and it is a matter of general consent that color contributes to correct flavor identification (Garber, Hyatt, \& Starr, 2000; Moir, 1936). In recent years, researchers have started to acknowledge the importance of the color of the package as well as of the food itself (Becker, van Rompay, Schifferstein, \& Galetzka, 2011). Color in the context of food is important for various reasons: It enables the consumer to create expectations about the perceived taste (Hoegg \& Alba, 2007); it influences the perceived texture of the food (Chylinski, Northey, \& Ngo, 2015); and it may assist consumers in making healthier food choices (Koenigstorfer, Groeppel-Klein, Kamm, Rohr, \& Wentura, 2012). In particular, red and green are relevant in this case because green may evoke environmental cues (Parguel, Benoît-Moreau, \& Russell, 2015), whereas red is a color that creates arousal and excitement (Labrecque \& Milne, 2012).

\footnotetext{
* Corresponding author.

E-mail address: sarah.lyons@nofima.no (S.J. Lyons).
} 
Although some studies rely on color preference and appropriateness as dependent variables (Bottomley \& Doyle, 2006; Miller \& Kahn, 2005), other studies show that color preference does not necessarily do justice to explaining consumer choice (Creusen \& Schoormans, 2005). Given that color has been shown to affect price perception and perceived quality (Ampuero \& Vila, 2006; Ares \& Deliza, 2010; Labrecque \& Milne, 2013; Loose \& Szolnoki, 2012), this study combines the impression of high price and quality by investigating premiumness as the dependent variable in an exploratory manner.

In our examination of how red and green may benefit premium products, the literature suggests it is necessary to consider simultaneously the type of product in question and its positioning, and whether the product design elements should match or mismatch (Bottomley \& Doyle, 2006). Thus, we turn to the literature on hedonic versus utilitarian consumption and congruent and incongruent color choice in that respect.

\subsection{Hedonic versus utilitarian product types and framing}

Consumption is motivated by hedonic or utilitarian factors, and products often are categorized accordingly as primarily hedonic or primarily utilitarian (Hirschman \& Holbrook, 1982). Examples of primarily hedonic products are a hot fudge sundae and a movie pass, whereas toothpaste and a spiral notebook are primarily utilitarian (Strahilevitz \& Myers, 1998). Hedonic benefits are multisensory, experiential, and joyful benefits, whereas utilitarian benefits offer a practical and instrumental advantage (Dhar \&Wertenbroch, 2000; Strahilevitz \& Myers, 1998). There is a fundamental difference in the type of goal that hedonic and utilitarian benefits help to achieve (Chernev, 2004). Consumers expect the fulfillment of prevention goals on the utilitarian dimension and the fulfillment of promotion goals on the hedonic dimension (Chitturi, Raghunathan, \& Mahajan, 2007). Understanding the hedonic versus utilitarian nature of the product is critical in a marketing sense, as the nature of the good may be important for consumer reactions such as willingness to pay for organic products (van Doorn \& Verhoef, 2011).

Central to the separation of hedonic and utilitarian products is that the distinction is not absolute, as hedonic products may possess utilitarian benefits and utilitarian products may possess hedonic benefits (Okada, 2005). Thus, although products essentially fall into one category, marketers can frame their offerings based on their hedonic or utilitarian benefits. For instance, one can position a dessert hedonically as the "Bailey's Irish Cream Cheesecake" or in a more utilitarian fashion as "Cheesecake deLite" (Okada, 2005), or a cellphone and a laptop can be described with superior hedonic and utilitarian benefits (Chitturi, Raghunathan, \& Mahajan, 2008). Framing a good hedonically or in relation to its utilitarian qualities triggers different consumer reactions (Raghunathan, Naylor, \& Hoyer, 2006).

\subsection{Congruence versus incongruence for product design and color}

Heckler and Childers (1992) conceptualize congruency with the dimensions relevancy and expectancy. Relevancy refers to the degree to which the information provided by the stimuli aids to or hinders the audience in identifying the communicated message, and expectancy refers to the degree to which the information or item is in line with a determined structure or schema. In sum, relevancy and expectancy contribute to the notion of congruence from the consumers' perceptive, whereas the lack of relevance and expectancy lead to perceived incongruence (Fleck \& Quester, 2007).

The literature offers various perspectives on the benefits of applying congruence versus incongruence in product design and marketing communication. Some scholars support the notion that congruence may enhance the perceived brand or product value (Erdem \& Swait, 1998, 2004). In contrast, a body of work supports the moderate incongruity effect, which implies that consumers view moderately incongruent products more favorably than those that are congruent or extremely incongruent (Meyers-Levy \& Tybout, 1989; Peracchio \& Tybout, 1996; Stayman, Alden, \& Smith, 1992). For example, Fleck and Quester (2007) found in their study of congruency for sponsorship that a certain level of mismatch between the sponsor and the event contributes to an unexpectedness or surprise that enhances positive evaluations. They conclude, however, that the associations will fail to make an impact if the sponsor is unsuccessful in communicating a certain level of relevancy.

In the current research, we are interested in the congruence between the communicated product benefit and the packaging color. Prior studies have suggested that there is a link between the attributes of a product and the affective reactions or symbolic meanings attached to a particular color (Huang \& Lu, 2016). The underlying psychological mechanism of color reactions often are found in the division of warm and cold colors. Warm colors are those with long wavelengths such as red, orange, and yellow, whereas cool colors are those with short wavelengths such as blue, green, and white (Chebat $\&$ Morrin, 2007). The opposite effect of colors with long and short wavelengths has been established in studies across the domains of psychology, advertising, and marketing (Bellizzi, Crowley, \& Hasty, 1983; Bellizzi \& Hite, 1992; Madden, Hewett, \& Roth, 2000; Puzakova, Kwak, Ramanathan, \& Rocereto, 2016). Cool colors have a calming effect on individuals and warm colors have an arousing effect (Grossman \& Wisenblit, 1999).

The division of warm and cool colors is not absolute, as Crowley (1993) suggested that all colors have an arousal component and an evaluative component. Color associations are context dependent and depend on the product (Grossman \& Wisenblit, 1999; Holmes \& Buchanan, 1984). On this note, Grossman and Wisenblit (1999) suggested that the twofold component of color may be seen in the view of associative learning; consumers create attitudes through a belief formation of a cognitive process and through an emotional process in terms of a affect transfer (Kim, Allen, \& Kardes, 1996). Due to the typical marketing practice of using green to promote utilitarian benefits, such as ecological (Parguel et al., 2015), and red to promote hedonic benefits, such as excitement and stimulation (Labrecque \& Milne, 2012), it is reasonable to assume that consumers have learned to associate green with utilitarian and red with hedonic. Indeed, Bottomley and Doyle (2006) found that red is more strongly associated with hedonic products and green more strongly associated with utilitarian products.

With this backdrop, we argue that consumers would consider packaging colors as either congruent or incongruent with a marketing message. Two streams of research on colors and package design shed light on how consumers react to congruence and incongruence, and indicate how perceptions of premiumness may be a function of either. The first stream of research suggests that consumers prefer package design elements that are congruent with the product type and positioning (Ares \& Deliza, 2010). For example, Bottomley and Doyle (2006) found that consumers prefer congruence between product type and logo color (i.e., utilitarian colors enhance consumers' perception of utilitarian products and hedonic colors enhance consumers' perception of hedonic products).

A proposed explanation for the positive effect of congruence on consumer evaluations is brand credibility (Van Rompay \& Pruyn, 2011). When consumers experience congruence between different marketing mix elements, they consider the brand or product as more credible (Reber \& Schwarz, 1999), which enhances their evaluations of product quality (Erdem \& Swait, 1998, 2004). Given the view of premiumness as an evaluation based on a utilitarian quality component (Quelch, 1987), it seems likely that color-product congruence would have a positive effect on perceived premiumness.

The other stream of research suggests that consumers prefer product design elements that are moderately incongruent with the product type and positioning (Blijlevens, Carbon, Mugge, \& Schoormans, 2012). An 
explanation for this moderate incongruity effect is that incongruence is more arousing and emotionally stimulating than congruence (Campbell \& Goodstein, 2001). The novelty of the object increases processing, leading to the resolution of the incongruity and enjoyment of the product. As suggested by Anselmsson et al. (2014), a hedonic component plays an important role in creating premium perceptions. Hence, it seems likely that color-product incongruence also would have a positive effect on perceived premiumness.

A study by Noseworthy and Trudel (2011) helps resolve the ambiguity provided by these seemingly contradictory theories. They suggest that a utilitarian versus a hedonic product positioning would moderate consumers' tendency to prefer congruence or incongruence. An underlying premise for their theory is that consumers seek to fulfill both utilitarian and hedonic goals when purchasing a product. Accordingly, when a product is positioned based on utilitarian benefits, consumers prefer a moderately incongruent product form because that also provides them hedonic benefits. On the contrary, when a product is positioned on hedonic dimensions, consumers prefer the congruent product form to the moderately incongruent form because congruence provides assurance of the product's functionality. As discussed previously, a product may be evaluated as either hedonic or utilitarian based on how it is positioned through marketing messages as well as on its inherent nature. Thus, we argue that the nature of the product, classified as either hedonic or utilitarian, would influence consumers' tendency to prefer congruence or incongruence.

Based on this theoretical background, we suggest that it is not the color per se that contributes to premium evaluations but how the color matches with the marketing message and the nature of the product. As indicated previously, premium evaluations consist of a utilitarian dimension, including a high product quality and a price that is above average (Quelch, 1987; Vigneron \& Johnson, 2004), as well as a hedonic dimension, such as product uniqueness and status (Anselmsson et al., 2014). It is when these two dimensions are combined that the highest level of premiumness is likely to be evoked. Accordingly, when one of these dimensions are already fulfilled due to the inherent benefits of the product, the other dimension should be more important to emphasize through the packaging communication. Thus, we propose that the extent to which a match or a mismatch between colors and marketing messages leads to the highest premium evaluations depends on whether the inherent benefits provided by the product type are primarily utilitarian or hedonic. Specifically, we suggest that, for a product that is primarily hedonic, congruence between the marketing message and color is favorable, whereas for a primarily utilitarian product, incongruence between marketing message and color will work better.

A study by Mehta and Zhu (2009) provided preliminary evidence for the latter effect. They showed that for toothpaste (a utilitarian product), a utilitarian message (prevents cavities) in combination with a hedonic color (red) was a better fit, and on the other hand that a hedonic message (whitens teeth) with a utilitarian color (blue) also led to higher preferences. Although they did not test this effect for hedonic products, our suggestion implies that they would find the opposite effect if the product was primarily hedonic and not primarily utilitarian.

In sum, we build on the premise that the color on the package, in addition to the marketing message and the nature of the product, will guide consumers in their perceptions of the perceived level of premiumness. We build on the same division of colors as done by Bottomley and Doyle (2006), yet in line with our conzeptualizion of hedonic and utilitarian products, we use the terminology hedonic colors to refer to warm colors and utilitarian colors to refer to cool colors.

\subsection{Hypothesis}

The current study proposes that a hedonic color (red) and a utilitarian color (green) will evoke different levels of perceived premiumness based on a hedonic versus utilitarian framing when tested on two goods of different nature. Red and green are chosen for this purpose because they represent a hedonic and utilitarian color and because the opposite effect of red and green is well established (Bottomley \& Doyle, 2006; Elliot, Maier, Moller, Friedman, \& Meinhardt, 2007; Fehrman \& Fehrman, 2004). Formally stated, we suggest that:

H1. A primarily hedonic product, framed on hedonic product benefits, will receive higher premiumness evaluations if the color on the packaging is a hedonic color (rather than if the color is utilitarian).

H2. A primarily hedonic product, framed on utilitarian product benefits, will receive higher premiumness evaluations if the color on the packaging is a utilitarian color (rather than if the color is hedonic).

H3. A primarily utilitarian product, framed on hedonic product benefits, will receive higher premiumness evaluations if the color on the packaging is utilitarian (rather than if the color is hedonic).

H4. A primarily utilitarian product, framed on utilitarian product benefits, will receive higher premiumness evaluations if the color on the packaging is a hedonic color (rather than if the color is utilitarian).

Two experimental studies test the hypotheses. Study 1 tests hypotheses 1 and 2 with a product of a hedonic nature. Study 2 replicates Study 1 to test hypotheses 3 and 4 with a product of a utilitarian nature.

\section{Study 1: The coffee study}

We first ran a pre-test with the aim of identifying a product that was mainly hedonic yet also might be sold based on its utilitarian benefits. A test of hedonic versus utilitarian products was given to 21 undergraduate business students at the Arctic University of Norway. The framing pre-test was conducted separately from the main study. The subject pool was the same, but the participants were drawn from a different class. The students were given a list of the following products: shrimp, salmon, cod, dietary supplements, juice, sparkling water, coffee, yogurt, king crab, vitamin water, coconut water, and organic food. No photo of the products was shown, and the students were provided only with a list of the product types. The students were asked to mark if they perceived the product as primarily delicious and enjoyable (hedonic), primarily nutritious and healthy (utilitarian), or equally delicious and enjoyable as nutritious and healthy. This method follows existing procedures for separating hedonic and utilitarian products (Dhar \& Wertenbroch, 2000).

Based on the results of the pre-screening of product types, coffee was chosen as the product for Study 1 because a majority of students classified it as primarily hedonic (15 out of 21 subjects, $\chi^{2}=3.857$, $p<.05)$. Moreover, coffee was suitable for the study because it can be framed in a utilitarian or hedonic manner (Labbe, Ferrage, Rytz, Pace, \& Martin, 2015).

\subsection{Design and materials}

A 2 (product benefits: hedonic versus utilitarian) $\times 2$ (color: green versus red) between-subject experimental design was employed. Product benefits were manipulated as either hedonic or utilitarian. To frame the coffee based on product benefits, a product package was presented with a text description of the coffee under the image of the product. The text presented on the hedonic framing was based on highlighting a promotional goal (outstanding taste). The utilitarian framing highlighted a prevention goal (does not stain your teeth) (Chitturi et al., 2008).

In the hedonic product benefits condition, the following text was presented to frame the coffee as a hedonic product: "After several years of success in the Italian market, the Italian barista Francesco Sanapo, a star barista in the Italian coffee scene, launches his renowned coffee in the Norwegian market. Francesco Sanapo coffee was voted the best coffee on the market at the 'European Food Awards 2016' in Rome. A 


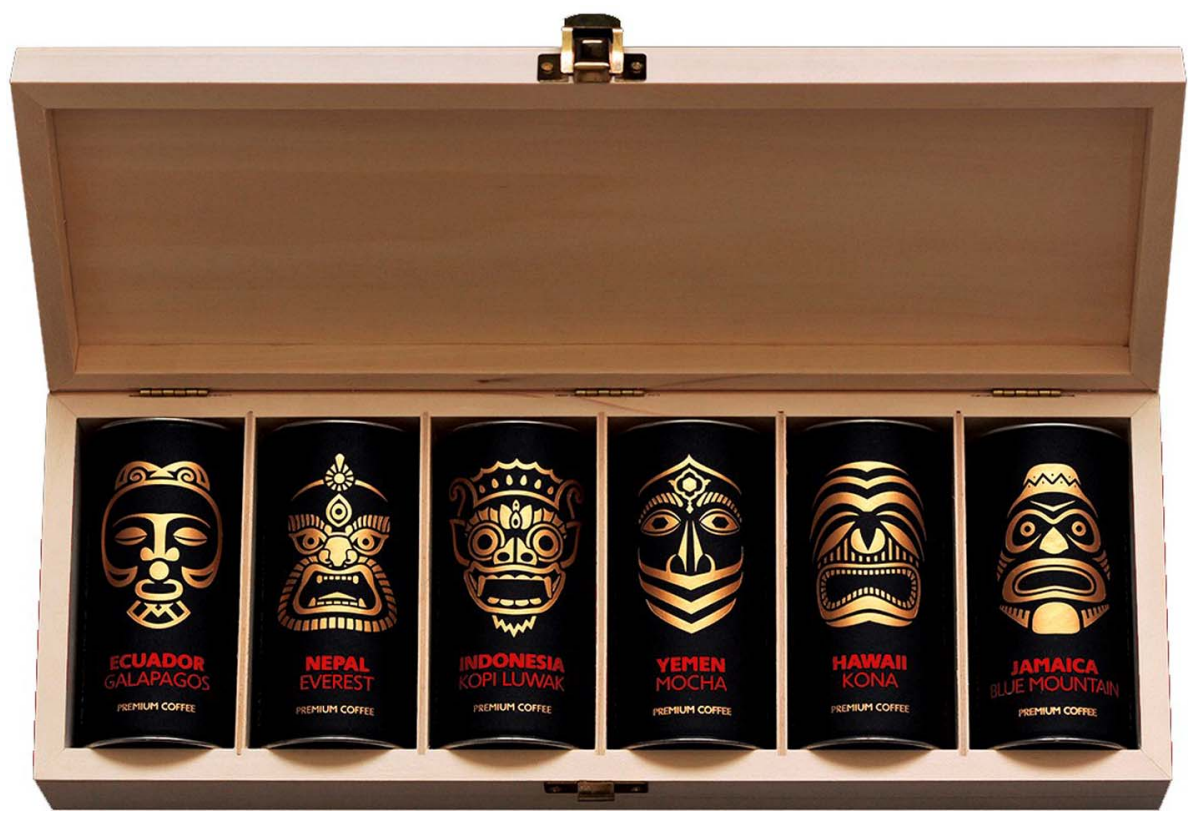

Image 1. A coffee package with red text. (For interpretation of the references to colour in this figure legend, the reader is referred to the web version of this article.) jury of international bartenders, baristas and chefs described the coffee as the market's most tasty coffee. The coffee is to be offered in the Norwegian market with the flavors of dark roast, light roast, caramel, vanilla, chocolate and the new taste pumpkin \& cinnamon. Francesco Sanapo coffee is sold in selected stores in Norway and the price is NOK 249, - for $1 \mathrm{~kg}$."

The following text was used to manipulate the product as a utilitarian product: "After several years of success in the Italian market, the Italian barista Francesco Sanapo, a star barista in the Italian coffee scene, launches his renowned coffee in the Norwegian market. Francesco Sanapo coffee is made with a new technology that roasts coffee beans in a smarter way. Research shows that when the coffee beans are roasted in this way, the coffee does not stain your teeth like regular coffee does. That means that you can drink as much as you want of this coffee, without discoloring your teeth. The coffee flavor is not affected by this. Francesco Sanapo coffee is sold in selected stores in Norway and the price is NOK 249, - for $1 \mathrm{~kg}$."
To manipulate color, we followed the procedure used in previous research by creating a mock package in Adobe Photoshop (Labrecque \& Milne, 2012). The design image of a coffee package was imported, and a professional designer manipulated the photos in Photoshop CS5, v.12.0. In accordance with previous studies, saturation and value were kept constant and only hue was manipulated. Previous measures were adopted by setting saturation at 87 , value at 72 , and hue at 0 (red) and 140 (green) (Elliot et al., 2007).

Only the text of the flavor label on the coffee package was manipulated, and the background was kept constant (black), creating a premium association to the product (Ampuero \& Vila, 2006; Ares \& Deliza, 2010; Labrecque \& Milne, 2013). The flavor label was manipulated for aesthetic reasons. We wanted the text on the package to look like a real product and be convincing to consumers, and thus we manipulated only the flavor label. Images 1 and 2 show the stimuli presented in Study 1.

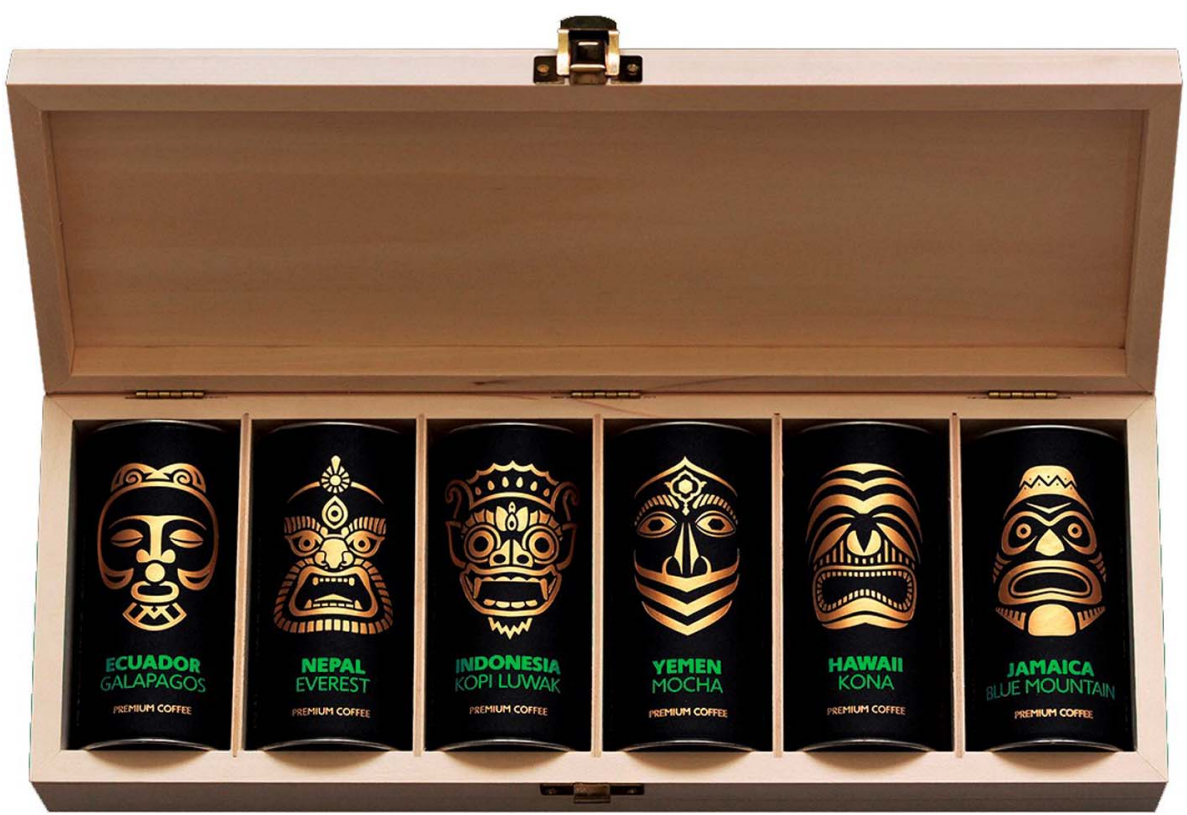

Image 2. A coffee package with green text. (For interpretation of the references to colour in this figure legend, the reader is referred to the web version of this article.) 


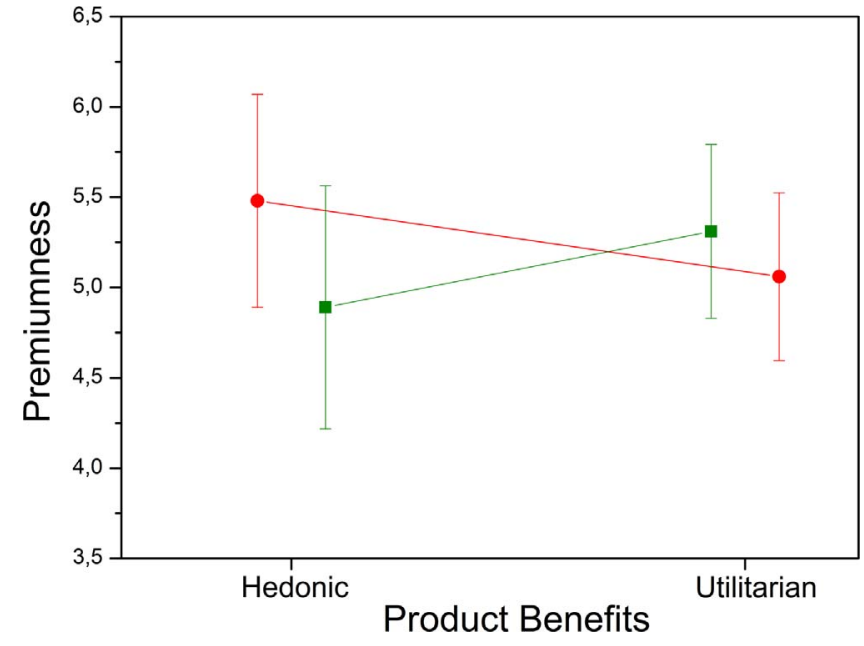

Fig. 1. Estimated marginal means and standard deviations of premium coffee.

\subsection{Participants and procedure}

At the Arctic University of Norway, 132 undergraduate business students $(48 \%$ male and $52 \%$ female; age 18-53, $M=23.64$, $S D=6.16$ ) participated in the study (two respondents were removed from the original sample because they reported color blindness). Participants in this study were randomly assigned to one of the $2 \times 2$ experimental conditions. The study was distributed through the software program Qualtrics, and the conditions were randomly assigned in Qualtrics.

The study was conducted in an auditorium with no windows, only auditorium lighting.

The students participated in the study at the beginning of the class on their own laptops. They were instructed to not speak with each other while reading the description and answering the questions. The study consisted of a short introduction, informing them that the purpose of the study was to evaluate a new type of coffee being considered for the Norwegian market. They were given the option to quit the study at any time, and participation was voluntary. Following the introduction, the students were given the product description with a photo of the product package.

Next, the participants were asked to describe to what degree they perceived the product to be one that is "healthy and nutritious" or delicious." Testing the manipulation of framing was achieved by asking if the respondent found the coffee to be mainly utilitarian (useful and practical), mainly hedonic (enjoyable and pleasing to the senses), both utilitarian and hedonic, or as neither (Dhar \& Wertenbroch, 2000; Strahilevitz \& Myers, 1998).

The first question asked after the test of the manipulation was to rate, on a scale from 1 to 7 , to what degree they evaluated this coffee as "premium coffee." Next, the participants were asked to evaluate, on the same scale, to what degree they liked the "package appearance." As a final question, we asked for age and gender. To exclude students with color blindness, we included a question at the end of the survey asking the respondents to report if they were color blind. This procedure for excluding color blindness follows color studies such as Clydesdale (1993). In total, it took students about $3 \mathrm{~min}$ to complete the study.

\subsection{Results}

The results confirmed that the framing of the product benefits worked. The majority of the students in the hedonic condition evaluated the coffee as primarily hedonic (64 out of 66 subjects, $\chi^{2}=58.242, p<.001$ ), and the majority of the subjects in the utilitarian condition evaluated the coffee as primarily utilitarian (52 out of 66 subjects, $\chi^{2}=21.879, p<.001$ ).
A two-way ANOVA was conducted to examine the effects of color (red versus green) and product benefits (superior hedonic benefits versus superior utilitarian benefits) on premiumness. Findings in this experiment support hypotheses 1 and 2 . There was a significant interaction effect between product benefits and color on premiumness ( $\mathrm{F}$ $\left.(1128)=4.707, p<.05, \mathrm{n}_{\mathrm{p}}{ }^{2}=0.035\right)$, whereas the main effects were not significant (color $\mathrm{F}(1128)=0.795, p=.374, \mathrm{n}_{\mathrm{p}}^{2}=0.006$; product benefit $\left.\mathrm{F}(1128)=0.001, p=.981, \mathrm{n}_{\mathrm{p}}{ }^{2}=0.000\right)$. Fig. 1 depicts these findings.

There was not a statistically significant main effect of color on liking of the package appearance $\left(\mathrm{F}(1128)=0.067, p=.796, \mathrm{n}_{\mathrm{p}}{ }^{2}=0.001\right)$ or a main effect of product benefits on liking of the package appearance $\left(\mathrm{F}(1128)=0.031, p=.860, \mathrm{n}_{\mathrm{p}}{ }^{2}=0.000\right)$. The interaction effect between product benefit and color on liking of package appearance also was not significant $\left(\mathrm{F}(1128)=0.402, p=.527, \mathrm{n}_{\mathrm{p}}{ }^{2}=0.003\right)$.

\subsection{Discussion}

The results from Study 1 provide evidence for hypothesis 1 and 2 . The results suggest that a primarily hedonic product, framed on hedonic product benefits, will receive higher evaluation of premiumness if the packaging color is a hedonic color, whereas a primarily hedonic product, framed on utilitarian product benefits, will receive higher premiumness evaluations if the packaging color is a utilitarian color.

\section{Study 2: The cod study}

Building on the interaction effect found in Study 1, the aim of Study 2 was to test a product of utilitarian nature (hypothesis 3 and 4). Based on the same pre-test of products as Study 1 , cod was chosen as a product for Study 2. The majority of the students classified cod as primarily utilitarian ( 16 out of 21 subjects, $\chi^{2}=5.762, p<.05$ ). Cod also is a product that may be framed on hedonic conditions based on findings that confirm that taste is a significant determinant for fish consumption (Verbeke \& Vackier, 2005).

\subsection{Design and materials}

As in Study 1, a $2 \times 2$ experimental design was employed. Product benefits were manipulated either as hedonic or utilitarian. In the hedonic condition, the following text was presented to frame cod as a hedonic product: "We are now in the season for cod, which means the best time for tasty cod. The cod tenderloin from Strom is bone free and vacuum packed in a delicate way. The cod fillets are packed within three hours of harvesting and are sold completely fresh to preserve the good and fresh taste. The cod fillets taste good raw, baked, or fried. Here are some serving tips for how to enjoy cod fillets:

- Oven baked cod with parsnip purée and chorizo salad with pomegranate

- Homemade uramaki with cod, avocado, cucumber and chili mayonnaise

- Ceviche with rosé pepper and coriander

The Cod from Strom is sold in selected stores in Norway. The price for $400 \mathrm{~g}$ ( 2 servings) is NOK 120, -."

The utilitarian condition was framed as follows: "We are now in the season for cod, which means the best time for healthy and nutritious cod. The Norwegian Arctic cod spends most of the life in the Barents Sea, becoming rich in nutrition, before migration to the Norwegian Atlantic coast. Strom cod fillets are packaged within $3 \mathrm{~h}$ after catching and sold completely fresh. It is therefore very rich in proteins, vitamins, and minerals. A portion of cod covers the recommended daily intake of Omega-3 fatty acid, and will prevent you from catching colds and having low energy. The nutritional content of cod fillet per $100 \mathrm{~g}$ is $75 \mathrm{kcal}, 17 \mathrm{~g}$ of protein, $0.7 \mathrm{~g}$ of fat, and $0 \mathrm{~g}$ of carbohydrate. Strom Cod 

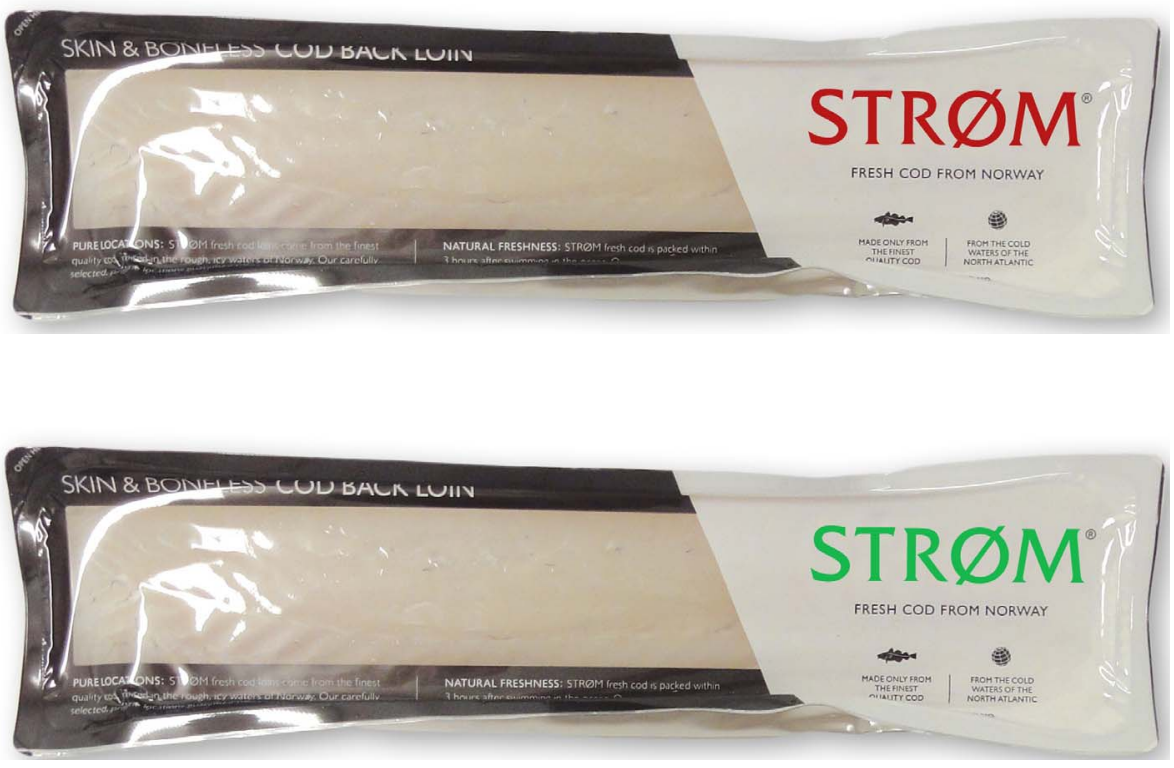

Image 3. A cod package with red text. (For interpretation of the references to colour in this figure legend, the reader is referred to the web version of this article.) is sold in selected stores in Norway. The price for $400 \mathrm{~g}$ ( 2 servings) is NOK 120, -."

Following the same procedure as in Study 1, a professional designer created a product package by manipulating photos in Photoshop CS5, v.12.0. As in Study 1, hue, saturation and value were kept constant, and only the hue of the text on the package was manipulated. Images 3 and 4 show the stimuli presented in Study 2.

\subsection{Participants and procedure}

At the Arctic University of Norway, 110 undergraduate business students $(26 \%$ male and $74 \%$ female; age $19-45, M=21.30$, $S D=3.64)$ participated in the study. None of the participants reported color blindness, and thus all respondents were retained. The participants in Study 2 consisted of a different group of students from the same subject pool; however, none of the students participated in both the studies. A $2 \times 2$ between-subject experimental design was employed. The procedure in Study 2 was the same as that explained in Study 1.

\subsection{Results}

As in Study 1, the manipulation was tested by asking the respondents to evaluate whether they found the cod product mainly utilitarian or mainly hedonic, both utilitarian and hedonic, or neither (Dhar \& Wertenbroch, 2000; Strahilevitz \& Myers, 1998). The majority of the students in the utilitarian condition evaluated the cod as primarily utilitarian (52 out of 54 subjects, $\chi^{2}=46.296, p<.001$ ), and the majority of those in the hedonic condition evaluated the cod as primarily hedonic ( 38 out of 56 subjects, $\chi^{2}=7.143, p<.01$ ).

A two-way ANOVA was conducted to examine the effects of two different colors (red versus green) and two product benefits (superior hedonic benefits versus superior utilitarian benefits) on premiumness. Findings in this experiment support hypothesis 3 and 4. There was a statistically significant interaction effect of color and consumption situation on premiumness $\left(\mathrm{F}(1106)=4.356, p<.05, \mathrm{n}_{\mathrm{p}}{ }^{2}=0.039\right)$, whereas the main effects were not significant (color $\mathrm{F}(1106)=1535$, $p=.218, \mathrm{n}_{\mathrm{p}}{ }^{2}=0.014$; product benefit $\mathrm{F}(1106)=0.743, p=.391$, $\left.\mathrm{n}_{\mathrm{p}}{ }^{2}=0.007\right)$. Fig. 2 depicts these findings.

There was no significant interaction effect between product benefit and color on liking of the package appearance $(\mathrm{F}(1106)=0.560$, $\left.p=.456, \mathrm{n}_{\mathrm{p}}{ }^{2}=0.005\right)$, and the main effects also were not significant (color $\mathrm{F}(1106)=0.347, p=.557, \mathrm{n}_{\mathrm{p}}^{2}=0.003$; product benefit $\mathrm{F}$ $\left.(1106)=1.432, p=.234, \mathrm{n}_{\mathrm{p}}^{2}=0.013\right)$.

\subsection{Discussion}

In line with our prediction, the results from Study 2 demonstrate the opposite effect to that of Study 1 . This supports hypotheses 3 and 4, which state that, when the product is primarily utilitarian, such as cod, consumers will evaluate the product as more premium if the framing of the marketing message and the color are incongruent. A primarily utilitarian product, framed on hedonic product benefits, will receive higher premiumness evaluations if the packaging color is utilitarian, whereas a primarily utilitarian product, framed on utilitarian product benefits, will receive higher premiumness evaluations if the packaging color is a hedonic color.

\section{General discussion}

The current study presents a novel approach to premiumness. Our results build on the notion that utilitarian and hedonic components are a part of the premium construct (Anselmsson et al., 2014; Quelch, 1987; Vigneron \& Johnson, 2004). Previous studies have found that certain colors may lead to higher price and quality perceptions (Ampuero \& Vila, 2006; Ares \& Deliza, 2010; Labrecque \& Milne, 2013; Loose \& Szolnoki, 2012). We build upon this and suggest that, to

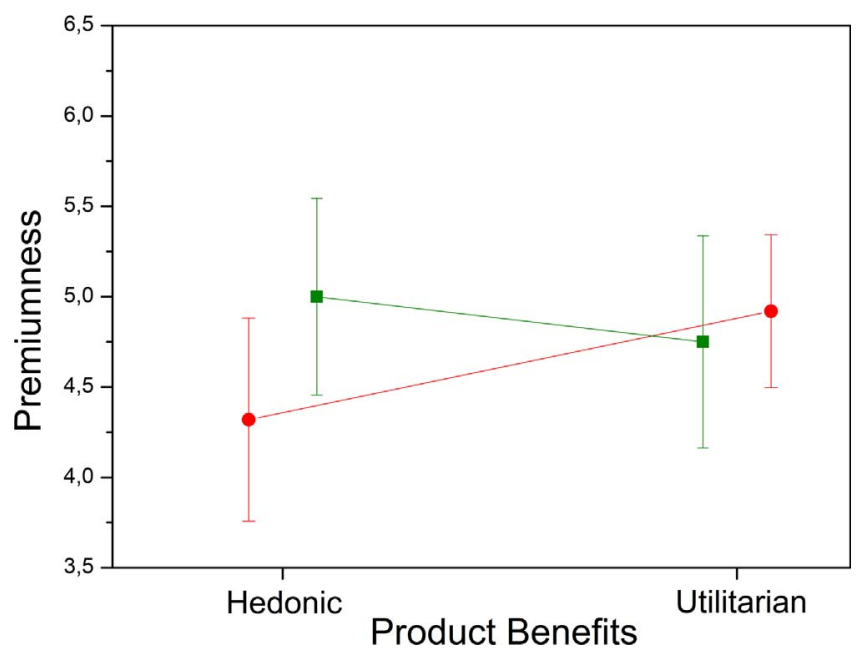

Fig. 2. Estimated marginal means and standard deviations of premium cod. 
enhance the premium associations through color on the package, congruence and incongruence between the color and marketing message play an important role.

Across the two studies, we explored the notion of how color and the marketing message can enhance premium evaluations. Our findings suggest evidence for the notion that whether congruence or incongruence between the marketing message and the color is beneficial for creating premium evaluations depends on whether the premium product is primarily hedonic or primarily utilitarian. The coffee study suggests that for a primarily hedonic product congruence between the marketing message and color is preferred, whereas the cod study demonstrated the opposite.

The reasons for why premiumness was achieved by different mechanisms in the coffee and cod studies may be found in the literature on utilitarian versus hedonic benefits, which states that utilitarianism precedes hedonism until utilitarian expectations are met (Chitturi et al., 2007). As articulated by Okada (2005), one needs to "earn the right to indulge." This notion is transferable to product design (Noseworthy \& Trudel, 2011). We advance the literature on congruence and incongruence (Meyers-Levy \& Tybout, 1989; Peracchio \& Tybout, 1996; Stayman et al., 1992) by suggesting that the mechanism explains how color and marketing message congruence and incongruence may create premium associations.

In the case of a hedonic product, such as coffee, consumers expect hedonic benefits, yet they also want to be reassured that the product provides a certain degree of utilitarian benefits. Accordingly, Noseworthy and Trudel (2011) suggested that for hedonic products, a moderately incongruent product design is not beneficial because incongruence causes consumers to perceive less utilitarian benefits. This explanation applies for our findings as well. Based on the notion that both a hedonic and utilitarian component are necessary for creating premiumness perceptions, incongruence between the marketing message and color choice will for primarily hedonic products create a utilitarian uncertainty that weakens the premium evaluations. On the other hand, congruence will satisfy the utilitarian need and increase premium evaluations for these types of products. In the coffee study, a reason for why incongruence between the color and the marketing message created lower premium associations than congruence may be because the incongruence created a utilitarian uncertainty. This finding is in line with the premise that utilitarianism needs to be met before hedonism (Chitturi et al., 2007; Okada, 2005). When a product is primarily hedonic, we find support for the results of Bottomley and Doyle (2006), stating that there should be congruence between the product type and the color choice.

On the contrary, in the case of a primarily utilitarian product, such as cod, the expectations are different. The consumers are familiar with the utilitarian benefits of a typical utilitarian product, and the utilitarian expectations for the product are already met. Thus, there is room for creating an element of excitement by incongruence between the framing of the color and the marketing message. The effect of excitement is in line with the study by Fleck and Quester (2007), who found that incongruence creates an unexpectedness that enhances positive evaluations. In our case, when the product was primarily utilitarian, we confirmed the benefits of the moderate incongruence effect (MeyersLevy \& Tybout, 1989; Peracchio \& Tybout, 1996; Stayman et al., 1992), and we find that moderate incongruence between color and the marketing message can benefit the perceived premium evaluations. Furthermore, these findings support the idea that premium evaluations consist of both a hedonic and a utilitarian component.

The study can assist marketing managers who offer premium food products. Because of the nature of the colors green and red, managers could be tempted to use green to highlight utilitarian benefits and red to evoke hedonic associations. This study introduces a new perspective. For hedonic products, such as coffee, our findings confirm that red combined with a hedonic message or green combined with a utilitarian marketing message may evoke premiumness. Moreover, we advance this by suggesting the opposite recommendation for a utilitarian product. If the strategy is to sell a utilitarian product-for instance, cod-with a marketing message focusing on utilitarian benefits, such as health benefits, a hedonic color (red) should be chosen to enhance premium evaluations. If the marketing strategy is to sell the utilitarian product with a marketing message focusing on hedonic benefits, such as excellent taste, a utilitarian color (green) is more beneficial for evoking an evaluation of premiumness.

\subsection{Limitations and future research}

This study is not without limitations. This work only employed the hues green and red and two different types of product, cod versus coffee. We employed a $2 \times 2$ between- subject design and replicated the design using two different product types. Alternatively, we would have employed a 2 (product benefit) $\times 2$ (color) $\times 2$ (product type) design, where a three-way interaction effect could have been tested. We encourage future studies to further explore mechanisms that contribute to creating premium associations across different products by incorporating the product types as a factor in the statistical model.

Furthermore, the employment of a student sample denotes a study design weakness. Although it is not uncommon for studies that investigate consumer perceptions of high-end goods to employ student samples (e.g. Vigneron and Johnson (2004)), it would be beneficial to understand if the color perceptions of premium products would be different for a purchasing group of higher income.

There are some weaknesses concerning the color presentation. Because the study was run on each student's laptop, the colors could have been portrayed differently on each laptop due to variations in screens and light strength on each computer. In future studies, the color balance should be secured by using the same laptops for all respondents.

The packages were designed to look like realistic products. In effect, there are some weaknesses with the packages. It must be noted that on the coffee package, the flavor label was manipulated, and on the cod package, the name of the brand was manipulated. Although the reason for this was aesthetic, it is a weakness of the study. In addition, the images should have been in higher resolution. We did not receive feedback from the participants for having difficulties with the writing on the packages; however, for future studies, we encourage higher resolution photos.

Another weakness of the study is the use of a self-reporting measurement to reveal color blindness. Although a number of studies have relied on self-reporting to eliminate participants who are color blind (e.g. Clydesdale (1993)), future color studies should test color blindness.

The current study provided an exploratory approach to understand how colors may enhance premium product associations. More research is required to fully understand how congruence and incongruence may apply to consumer evaluations of premium products.

\section{Acknowledgements}

The authors thank the Research Council of Norway for financial support (Grant 233751/E50).

\section{References}

Ampuero, O., \& Vila, N. (2006). Consumer perceptions of product packaging. Journal of Consumer Marketing, 23(2), 100-112. http://dx.doi.org/10.1108/ 07363760610655032.

Anselmsson, J., Vestman Bondesson, N., \& Johansson, U. (2014). Brand image and customers' willingness to pay a price premium for food brands. Journal of Product \& Brand Management, 23(2), 90-102. http://dx.doi.org/10.1108/JPBM-102013-0414.

Ares, G., \& Deliza, R. (2010). Identifying important package features of milk desserts using free listing and word association. Food Quality and Preference, 21(6), 621-628. http://dx.doi.org/10.1016/j.foodqual.2010.03.010. 
Becker, L., van Rompay, T. J., Schifferstein, H. N., \& Galetzka, M. (2011). Tough package, strong taste: The influence of packaging design on taste impressions and product evaluations. Food Quality and Preference, 22(1), 17-23. http://dx.doi.org/10.1016/j. foodqual.2010.06.007.

Bellizzi, J. A., Crowley, A. E., \& Hasty, R. W. (1983). The effects of color in store design. Journal of Retailing, 59, 21-45.

Bellizzi, J. A., \& Hite, R. E. (1992). Environmental color, consumer feelings, and purchase likelihood. Psychology \& Marketing, 9(5), 347-363. http://dx.doi.org/10.1002/mar. 4220090502.

Blijlevens, J., Carbon, C. C., Mugge, R., \& Schoormans, J. P. (2012). Aesthetic appraisal of product designs: Independent effects of typicality and arousal. British Journal of Psychology, 103(1), 44-57. http://dx.doi.org/10.1111/j.2044-8295.2011.02038.x.

Bottomley, P. A., \& Doyle, J. R. (2006). The interactive effects of colors and products on perceptions of brand logo appropriateness. Marketing Theory, 6(1), 63-83. http://dx. doi.org/10.1177/1470593106061263.

Bredahl, L. (2004). Cue utilisation and quality perception with regard to branded beef. Food Quality and Preference, 15(1), 65-75. http://dx.doi.org/10.1016/S09503293(03)00024-7.

Campbell, M. C., \& Goodstein, R. C. (2001). The moderating effect of perceived risk on consumers' evaluations of product incongruity: Preference for the norm. Journal of Consumer Research, 28(3), 439-449. http://dx.doi.org/10.1086/323731.

Chebat, J.-C., \& Morrin, M. (2007). Colors and cultures: Exploring the effects of mall décor on consumer perceptions. Journal of Business Research, 60(3), 189-196. http:// dx.doi.org/10.1016/j.jbusres.2006.11.003.

Chernev, A. (2004). Goal-attribute compatibility in consumer choice. Journal of Consumer Psychology, 14(1-2), 141-150. http://dx.doi.org/10.1207/s15327663jcp1401\&2_16.

Chitturi, R., Raghunathan, R., \& Mahajan, V. (2007). Form versus function: How the intensities of specific emotions evoked in functional versus hedonic trade-offs mediate product preferences. Journal of Marketing Research, 44(4), 702-714 doi.org/ 10.1509/jmkr.44.4.702.

Chitturi, R., Raghunathan, R., \& Mahajan, V. (2008). Delight by design: The role of hedonic versus utilitarian benefits. Journal of Marketing, 72(3), 48-63. http://dx. doi. org/10.1509/jmkg.72.3.48.

Chylinski, M., Northey, G., \& Ngo, L. V. (2015). Cross-modal interactions between color and texture of food. Psychology \& Marketing, 32(9), 950-966. http://dx.doi.org/10. 1002/mar.20829.

Clydesdale, F. M. (1993). Color as a factor in food choice. Critical Reviews in Food Science \& Nutrition, 33(1), 83-101. http://dx.doi.org/10.1080/10408399309527614.

Crowley, A. E. (1993). The two-dimensional impact of color on shopping. Marketing letters, 4(1), 59-69. http://dx.doi.org/10.1007/BF00994188.

Creusen, M. E., \& Schoormans, J. P. (2005). The different roles of product appearance in consumer choice. Journal of Product Innovation Management, 22(1), 63-81. http://dx. doi.org/10.1111/j.0737-6782.2005.00103.x.

Dhar, R., \& Wertenbroch, K. (2000). Consumer choice between hedonic and utilitarian goods. Journal of Marketing Research, 37(1), 60-71. http://dx.doi.org/10.1509/jmkr. 37.1.60.18718.

Elliot, A. J., Maier, M. A., Moller, A. C., Friedman, R., \& Meinhardt, J. (2007). Color and psychological functioning: The effect of red on performance attainment. Journal of Experimental Psychology: General, 136(1), 154. http://dx.doi.org/10.1037/00963445.136.1.154.

Erdem, T., \& Swait, J. (1998). Brand equity as a signaling phenomenon. Journal of Consumer Psychology, 7(2), 131-157. http://dx.doi.org/10.1207/ s15327663jcp0702 02.

Erdem, T., \& Swait, J. (2004). Brand credibility, brand consideration, and choice. Journal of Consumer Research, 31(1), 191-198. http://dx.doi.org/10.1086/383434.

Fehrman, K. R., \& Fehrman, C. (2004). Color: The secret influence (2nd ed.). Upper Saddle River, NJ: Prentice Hall.

Fleck, N. D., \& Quester, P. (2007). Birds of a feather flock together Ellipsis definition, role and measure of congruence: An application to sponsorship. Psychology \& Marketing, 24(11), 975-1000. http://dx.doi.org/10.1002/mar.20192.

Garber, L. L., Jr., Hyatt, E. M., \& Starr, R. G., Jr. (2000). The effects of food color on perceived flavor. Journal of Marketing Theory and Practice, 8(4), 59-72. http://dx.doi. org/10.1080/10696679.2000.11501880.

Grossman, P. R., \& Wisenblit, J. Z. (1999). What we know about consumers' color choices. Journal of Marketing Practice: Applied Marketing Science, 5(3), 78-88. http://dx.doi. org/10.1108/EUM0000000004565.

Heckler, S. E., \& Childers, T. L. (1992). The role of expectancy and relevancy in memory for verbal and visual information: What is incongruency? Journal of Consumer Research, 18(4), 475-492. http://dx.doi.org/10.1086/209275.

Hirschman, E. C., \& Holbrook, M. B. (1982). Hedonic consumption: Emerging concepts, methods and propositions. Journal of Marketing, 46(3), 92-101. http://dx.doi.org/10. 2307/1251707.

Hoegg, J., \& Alba, J. W. (2007). Taste perception: More than meets the tongue. Journal of Consumer Research, 33(4), 490-498. http://dx.doi.org/10.1086/510222.

Holmes, C. B., \& Buchanan, J. A. (1984). Color preference as a function of the object described. Bulletin of the Psychonomic Society, 22(5), 423-425. http://dx.doi.org/10 3758/BF03333865.

Kim, J., Allen, C. T., \& Kardes, F. R. (1996). An investigation of the mediational mechanisms underlying attitudinal conditioning. Journal of Marketing Research, 33(3), 318-328. http://dx.doi.org/10.2307/3152128.

Koenigstorfer, J., Groeppel-Klein, A., Kamm, F., Rohr, M., \& Wentura, D. (2012). The traffic light colors red and green in the context of healthy food decision-making. Advances in Consumer Research, 40, 945-946.

Labbe, D., Ferrage, A., Rytz, A., Pace, J., \& Martin, N. (2015). Pleasantness, emotions and perceptions induced by coffee beverage experience depend on the consumption motivation (hedonic or utilitarian). Food Quality and Preference, 44, 56-61. http://dx. doi.org/10.1016/j.foodqual.2015.03.017.

Labrecque, L. I., \& Milne, G. R. (2012). Exciting red and competent blue: the importance of color in marketing. Journal of the Academy of Marketing Science, 40(5), 711-727. http://dx.doi.org/10.1007/s11747-010-0245-y.

Labrecque, L. I., \& Milne, G. R. (2013). To be or not to be different: Exploration of norms and benefits of color differentiation in the marketplace. Marketing Letters, 24(2), 165-176. doi: To be or not to be different: Exploration of norms and benefits of color differentiation in the marketplace.

Huang, L., \& Lu, J. (2016). The impact of package color and the nutrition content labels on the perception of food healthiness and purchase intention. Journal of Food Products Marketing, 22(2), 191-218. http://dx.doi.org/10.1080/10454446.2014.1000434.

Loose, S. M., \& Szolnoki, G. (2012). Market price differentials for food packaging characteristics. Food Quality and Preference, 25(2), 171-182. http://dx.doi.org/10.1016/j. foodqual.2012.02.009.

Madden, T. J., Hewett, K., \& Roth, M. S. (2000). Managing images in different cultures: A cross-national study of color meanings and preferences. Journal of International Marketing, 8(4), 90-107. http://dx.doi.org/10.1509/jimk.8.4.90.19795.

Mehta, R., \& Zhu, R. J. (2009). Blue or red? Exploring the effect of color on cognitive task performances. Science, 323(5918), 1226-1229. http://dx.doi.org/10.1126/science. 1169144.

Meyers-Levy, J., \& Tybout, A. M. (1989). Schema congruity as a basis for product evaluation. Journal of Consumer Research, 16(1), 39-54. http://dx.doi.org/10.1086/ 209192.

Miller, E. G., \& Kahn, B. E. (2005). Shades of meaning: The effect of color and flavor names on consumer choice. Journal of Consumer Research, 32(1), 86-92. http://dx. doi.org/10.1086/429602.

Moir, H. (1936). Some observations on the appreciation of flavour in foodstuffs. Journal of the Society of Chemical Industry, 55(8), 145-148. http://dx.doi.org/10.1002/jctb. 5000550803.

Nielsen Company (2015). We are what we eat. Healthy eating trends around the word. Retrieved https://www.nielsen.com/content/dam/nielsenglobal/eu/nielseninsights/ pdfs/Nielsen\%20Global\%20Health\%20and\%20Wellness\%20Report $\% 20$ \%20January\%202015.pdf.

Noseworthy, T. J., \& Trudel, R. (2011). Looks interesting, but what does it do? Evaluation of incongruent product form depends on positioning. Journal of Marketing Research, 48(6), 1008-1019. http://dx.doi.org/10.1509/jmr.10.0384.

Okada, E. M. (2005). Justification effects on consumer choice of hedonic and utilitarian goods. Journal of Marketing Research, 42(1), 43-53. http://dx.doi.org/10.1509/jmkr. 42.1.43.56889.

Parguel, B., Benoît-Moreau, F., \& Russell, C. A. (2015). Can evoking nature in advertising mislead consumers? The power of "executional greenwashing". International Journa of Advertising, 34(1), 107-134. http://dx.doi.org/10.1080/02650487.2014.996116.

Peracchio, L. A., \& Tybout, A. M. (1996). The moderating role of prior knowledge in schema-based product evaluation. Journal of Consumer Research, 23(3), 177-192. http://dx.doi.org/10.1086/209476.

Puzakova, M., Kwak, H., Ramanathan, S., \& Rocereto, J. F. (2016). Painting your point: The role of color in firms' strategic responses to product failures via advertising and marketing communications. Journal of Advertising, 45(4), 365-376. http://dx.doi. org/10.1080/00913367.2016.1172384.

Quelch, J. A. (1987). Marketing the premium product. Business Horizons, 30(3), 38-45. http://dx.doi.org/10.1016/0007-6813(87)90035-8.

Raghunathan, R., Naylor, R. W., \& Hoyer, W. D. (2006). The unhealthy = tasty intuition and its effects on taste inferences, enjoyment, and choice of food products. Journal of Marketing, 70(4), 170-184. http://dx.doi.org/10.1509/jmkg.70.4.170.

Reber, R., \& Schwarz, N. (1999). Effects of perceptual fluency on judgments of truth. Consciousness and Cognition, 8(3), 338-342. http://dx.doi.org/10.1006/ccog.1999. 0386.

Stayman, D. M., Alden, D. L., \& Smith, K. H. (1992). Some effects of schematic processing on consumer expectations and disconfirmation judgments. Journal of Consumer Research, 19(2), 240-255. http://dx.doi.org/10.1086/209299.

Strahilevitz, M. A., \& Myers, J. (1998). Donations to charity as purchase incentives: How well they work may depend on what you are trying to sell. Journal of Consumer Research, 24(4), 434. http://dx.doi.org/10.1086/209519.

van Doorn, J., \& Verhoef, P. C. (2011). Willingness to pay for organic products: Differences between virtue and vice foods. International Journal of Research in Marketing, 28(3), 167-180. http://dx.doi.org/10.1016/j.ijresmar.2011.02.005.

Van Rompay, T. J., \& Pruyn, A. T. (2011). When visual product features speak the same language: Effects of shape-typeface congruence on brand perception and price expectations. Journal of Product Innovation Management, 28(4), 599-610. http://dx.doi. org/10.1111/j.1540-5885.2011.00828.x.

Verbeke, W., \& Vackier, I. (2005). Individual determinants of fish consumption: Application of the theory of planned behaviour. Appetite, 44(1), 67-82. http://dx.doi. org/10.1016/j.appet.2004.08.006.

Vigneron, F., \& Johnson, L. W. (2004). Measuring perceptions of brand luxury. The Journal of Brand Management, 11(6), 484-506. http://dx.doi.org/10.1057/palgrave. bm. 2540194 . 